\title{
Detecting God IN PRACTICES: TheOlOgY IN AN EMPIRICAL- THEOLOGICAL RESEARCH PROJECT
}

Author:

Rein Brouwer ${ }^{1,2}$

\author{
Affiliations: \\ ${ }^{1}$ Department of Practical \\ Theology, Protestant \\ Theological University, \\ The Netherlands
}

${ }^{2}$ Department of Practical Theology, University of

Pretoria, South Africa

Correspondence to:

Rein Brouwer

email:

rbrouwer@pthu.nl

Postal address:

2 Heidelberg Avenue, PO

Box 80.105, NL-3508 TC

Utrecht, The Netherlands

\section{Keywords:}

Critical realism; empirical theology; epistemology; methodology; ontology; research strategy

\section{Dates:}

Received: 18 Feb. 2010

Accepted: 14 Apr. 2010

Published: 19 Nov. 2010

How to cite this article:

Brouwer, R., 2010,

'Detecting God in

practices: Theology in

an empirical-theological

research project', HTS

Teologiese Studies/

Theological Studies 66(2),

Art. \#805, 5 pages. DOI:

10.4102/hts.v66i2.805

This article is available

at:

http://www.hts.org.za

Note:

This article was initially

presented as a paper at

the annual conference of

the Society of Practical

Theology in South Africa,

held at the University of

Pretoria in January 2010.

Prof. Rein Brouwer is a research associate of Prof.

Malan Nel, Director of

the Centre for Contextual

Ministry at the Faculty of

Theology of the University

of Pretoria, South Africa.

(c) 2010. The Authors. Licensee: OpenJournals

Publishing. This work

is licensed under the

Creative Commons

Attribution License.

\section{ABSTRACT}

What is the nature of reality in theological research and how can this 'theological' reality be known? Can we empirically research God's performance in reality? This article tries to find some common ground on this contested issue by presenting a debate between three Dutch practical theologians: Van der Ven, Immink, and Ganzevoort. Their positions on the theological dimension of empirical reality are traced, followed by some thoughts on critical realism and on a 'cataphysic' approach to empirical theological research, inspired by the theologian Alister McGrath and the philosopher of science Roy Bhaskar. This results in three concluding remarks. Firstly, realisme and social constructionism are not excluding options. Social constructions presuppose the existence of reality. Secondly, a stratified model of reality, perceiving the nature of reality as emergent, layered, and complex, points in the direction of multidisciplinary discourses and helps to avoid forms of reductionism. Thirdly, prioritizing the ontology of a stratified reality that reflects revelation, creates a common ground for the debate on the nature of theological reality.

\section{INTRODUCTION}

Sound remnants of an unfinished story.

Stone syllables, vestiges in desert sand.

Light words, once received, but from whom He who keeps Israel will not sleep.

These words were written by Huub Oosterhuis (2004:502), who is one of the prominent contemporary hymn-writers in the Netherlands. A former Roman Catholic priest, Oosterhuis became a household name for innumerable Dutch parishes and congregations. His poems, prayers, and hymns were welcomed as modern expressions of faith, mostly in left-wing, progressive faith communities. In the socalled 'Oosterhuis parishes' people sing only his psalm editions and songs. Sound remnants, for example, was set to music by his son Tjeerd, who, as a composer and producer of popular music, is more famous than his father is among the younger generation. The same goes, though even more so, for Oosterhuis' daughter, Trijntje, who is a well known jazz and pop singer and who is celebrated for her interpretation of Burt Bacharach songs.

The text of Sound remnants refers to Psalm 121:4 'Behold, he who keeps Israel will neither slumber nor sleep'. Psalm 121 is 'a pilgrim song', or a 'bedevaartslied' in Afrikaans. In most of the recent English versions, the Psalm is called 'a song of ascents'. The original Hebrew text reads 'sjier lama-aloot' meaning 'going up'. Such 'going up' makes the Psalm a fitting processional prayer for protection and an appropriate dedication to the Lord, who keeps us safe. From this song, Huub Oosterhuis took the words 'He who keeps Israel will not sleep', setting them in a different context, which might even be an alienating one. Nevertheless, it is a context that is rich in metaphor. I hear, for instance, the fading resonance of a Tibetan singing bowl. And I see hieroglyphs that are hard to decipher, the debris of ancient ruins covered with sand, and the reflection of a dead star, light-years away. There is a message, that is not immediately recognisable, but we know unequivocally that it is of ultimate importance to us. The message is metaphorical: 'He who keeps Israel will not sleep'. There is a ground for all being; there is someone who keeps; there is 'salus' (in Latin), or 'sjaloom' (in Hebrew), referring to salvation and liberation - all that we know for sure, in faith.

This hymn expresses the way in which I try to relate to Scripture and tradition - not only as a practising theologian, celebrating the liturgy, preaching a sermon, or dealing with congregational conflict, but also as a practical theologian and even as an empirical theologian. Relating to Scripture is part not only of the theological enterprise, but also of the academic and scientific theological enterprise as well. Theology reflects on the resonance of the 'sound remnants of an unfinished story'. Practical theology reflects on religious practices in which the stone syllables are interpreted, the vestiges are unearthed, and the words of light are received and identified. I use the word 'practices' in a broad sense, meaning action as well as intention and attitude, and incorporating the given circumstances and framework. 'Detecting God in practices' might be too provocative, but the real presence and performance of God is assumed, or, put another way, hoped for, perhaps just in the appearance of traces in practices. Theology is not only about the reception of, and the response or reaction to God's self-revelation, though these three elements can be empirically investigated (Van der Ven 1993:103-104). Somehow, the presence of the Spirit of Jesus, who is the face of God's promise, is part of the empirical reality. Theological concepts offer a unique epistemic access to this reality. I do not intend to revert to naive realism or fideism, and I also try to avoid naturalism or empirical atheism. Reflecting on the theological dimension of empirical religious research means, at least for me, finding some clarity on what the nature of reality in theological research is and how 'theological' reality can be known.

There is a particular reason why I am interested in the questions of ontology, epistemology and the theological dimension of reality. It is a particularly Dutch reason, related to the three practical theologians 
who are prominent in Dutch practical theology discourse: Hans van der Ven, Gerrit Immink and Ruard Ganzevoort.

I entered the field of practical theology in 1990, when I started working on my PhD. In the same year, Hans van der Ven's Entwurf einer empirischen Theologie was published, which was later on translated into English as Practical theology: An empirical approach (1993). Van der Ven's vigorous scientific approach to theology, especially to practical theology, had a major influence on me. His book was a milestone that marked the breakthrough of empirical theology, at least in the Netherlands. When studied theology at Utrecht University, during the 1980s, theology was 'classical theology' and not some sort of religious studies. At Utrecht University, at that stage, theology was Protestant and respectable and predominantly philosophical and systematic. Practical theology was considered to be slightly inferior, probably because Karl Barth did not think much of it. Only as 'applied theology' for ministerial education was practical theology regarded as useful. When Van der Ven's book was released. I was impressed by his methodology and research strategy. In order to be on a par with other sciences, especially the social sciences, theology must be empirical, according to Van der Ven. The scientific character of practical theology stands or falls with integrating empirical methodology in an intradisciplinary way. Inspired by Van der Ven's empirical rigorousness, I engaged in qualitative-empirical research from a Grounded Theory perspective, and wrote a dissertation on the professionalisation of Dutch ministry (Brouwer 1995). I received my $\mathrm{PhD}$ degree in the same year as did Ruard Ganzevoort, who was a fellow student in Utrecht. After I finished my dissertation, Gerrit Immink became holder of the chair of practical theology at Utrecht, and some years later I became a member of his staff.

By mentioning these three prominent Dutch practical theologians, I am setting the stage for what I want to say regarding the nature of reality in theological-empirical research. It might be strange to leave Gerben Heitink, another prominent Dutch colleague, out of the picture, but he was not particularly instrumental to my empirical theological education. So, the play I wish to present starts with three actors: Van der Ven, Immink and Ganzevoort. I proceed by tracing their positions along the theological dimension of empirical reality. Subsequently, I add some thoughts on critical realism and on the adoption of a 'cataphysic' approach to empirical theological research.

\section{RESEARCH PARADIGM AND STRATEGY}

In his address as president of the International Academy of Practical Theology, August 2009 in Chicago, Ganzevoort (2009) described the common ground from which, and the major decision points where, practical theologians tend to diverge. The framework that he offered at that stage could be perceived as a construction of the diverse, and sometimes colliding, narratives in practical theology. In general, Ganzevoort opts for a social constructionist research paradigm in practical theology, due to social constructionism transcending the dilemma of a foundationalist reference to revelation, on the one hand, and of a science of religion approach that does not do justice to the self-understanding of the believing community, on the other. Ganzevoort identifies the dilemmas with, respectively, Immink and Van der Ven. Immink questions Van der Ven's epistemic position, in terms of which the latter states that God cannot be the direct object of theology. The transcendence of God forms the limits of empirical research and empirical testing, according to Van der Ven (1993:103). Empirical research does not study God as such, but just the characteristics of the faith of religious people (Van der Ven 1993:111). A criterion for empirical theology is the sufficient empirical testability of theories and concepts, which is problematic for theology. What is the empirical reference of our concepts? Are they more than speculations, and can they be tested? Do they not suffer from insufficient demarcation, being too universal? What is the ontological quality of theological concepts? In order to fit the requirements of real science, there must be an aspectual and perspectival relationship between our concepts and reality. As a consequence, our concepts are momentary and individual, referring to the faith of people in the present (Van der Ven 1993:131).

Disputing Van der Ven's contentions, Immink (2004) advocates the importance of God's initiative and operativeness in reflecting on faith. Immink (2005:238-266) wants to do justice to the ontological status of the acting, speaking, and promising God. The 'subjectiveness' of God, the aseitas Dei, is a prime notion in Immink's thinking, with theological propositions being the only access to such 'subjectiveness'. Theological concepts do not converge with the referent of the word 'God'. Nevertheless, through our theological concepts, we are able to make contact with an external reality. Immink considers concepts as 'links' with reality. When we perceive God to be compassionate, we understand compassion to be a quality of God. Such perception implies the precedence of God in human faith. Ontology precedes epistemology, with existence having a logical priority over knowledge. Faith is really an experience of God as the Other and as the Word that created all things. In addition, faith lays claim to who God is - that is to say, a reality independent of human experience. Of course, faith is subjective, and has an affective dimension, which is a habit of the heart. However, there is also a propositional content to faith. Theological concepts and reflections on faith are propositions about God's performative presence. Immink (2004) admits, however, that the epistemic status of such propositions is confessional.

According to Ganzevoort, the presupposition of the existence of God loses its meaning outside the circle of believers, due to its confessional nature. From Ganzevoort's perspective, confessional propositions do not suffice for public theology. In order to move beyond the dispute between Immink and Van der Ven, Ganzevoort (2006a) presents a social constructionist approach to revelation. Although Immink (2002) and Van der Ven (2002) are critical of social constructionism, for the sake of argument I follow Ganzevoort (2006b:26) in his perception of the theological dimension of practical theology. Ganzevoort recognises that there is a fundamental discussion going on in the debate between Van der Ven en Immink. Does ontology precede epistemology, as Immink presumes, or is the ontology hidden behind the epistemology of human perspectives, as Van der Ven seems to intimate? Ganzevoort veers away from the subjectivity of God, as well as scientifically objectified faith, expressing a greater interest in how the faithful construct God's subjectivity. His focus shifts to the process of understanding our experiences of revelation. What are the different discourses on revelation, and how do these, potentially conflicting, discourses function in religious conversation? Social constructionism is not concerned with the ontological status of revelation, but with the performative dimension of the discourse on revelation. Theological language constructs a particular dialogue and relationship with other people, irrespective of its referential content. The language is more about purpose and human performance than it is about ontological reference and denotation. Ganzevoort perceives social constructionism as a way out of the cul-de-sac in which the dispute between Immink and Van der Ven seems to end up, with external realism vying against moderate conceptual realism, and with God as subject of theology vying with theology as objectifying faith. The opening that Ganzevoort (2006a:4) anticipates is the notion that we bring about divine actions through performative acts. By understanding our experiences as divine disclosure, the other reality becomes present in our world. For instance, transcendence is a term 'to describe the dynamics of human life, constantly surpassing the boundaries of our existing life worlds'. The concept does not refer to the difference of God's reality. Revelation is not limited to religious discourse. Self-transcendence, in the sense of crossing our boundaries in response to becoming addressed from the outside, is part of the human condition. From a social constructionist perspective, divine disclosure is constructed through social performance. 
In order fully to understand Ganzevoort's agenda, we need to realise that he is working towards a public theology. Public theology, as Ganzevoort (2006a:10) understands it, is the theologians' sharing of their methodological expertise that they perform in order to contribute to the hermeneutical analysis of public phenomena and in order to interpret the God-talk in popular culture. Society might be considered the preferred audience for Ganzevoort, in comparison with Van der Ven, who challenges the academia, and with Immink, who primarily regards himself as having been called to serve the church. Accordingly, it is possible to distinguish the different approaches from one another according to the purpose of their speech act. Such distinction, though perhaps being a simplification, might still be a worthwhile exercise. Whereas Immink looks for confessional persuasion, and Van der Ven strives for hermeneutic-communicative consensus, based on empirical research, Ganzevoort (2006b:11-31) tries to foster a public dialogue by making space for the legitimacy of different, and even colliding, narratives.

So far, I have described the different positions of three prominent Dutch practical theologians. I tend to side with all three of them on different aspects. While welcoming Van der Ven's empirical approach, I feel a close affinity with Immink's Word-theology, though I also understand Ganzevoort's assertion that we can only attain reality by way of our multiple interpretations, which are socially constructed. However, although I am interested in the best of all three worlds, my Dutch colleagues all have ended up 'going Dutch'. Their practical theology differs in terms of the audience they address (academy, church, or society), the discourse they prefer (empirical evidence, persuasion, or performance), the angle they take on the Goddimension in practices (aspectual perspectivity, subjectiveness, or interpretation), and the status they assign to theological statements (falsified hypotheses, propositions, and narratives in dialogue). In addition to such differences, Van der Ven, Immink, and Ganzevoort also opt for alternative research paradigms. They take distinctive positions on the issue of ontology and epistemology, even entering the paradigm issue from different directions. It is fair to say that, for Immink, ontology precedes epistemology. There is a reality independent of the human mind, which reality is independent from our mental functions and cognitive processes. Immink himself refers to such a standpoint as metaphysical or external realism. However, from a philosophy of science perspective we could call his position 'naive realism' or 'shallow realism' (Blaikie 2007:12-24). His epistemology could, in fact, be understood as 'neo-realism'. Van der Ven and Ganzevoort, in contrast, prioritise epistemology. Van der Ven's epistemology is inspired by Karl Popper's critical rationalism and falsificationism. Though Van der Ven does not deny an independent reality, he contends that the only way we can access such reality is through our mind, and through ideas or theories that need to be tested and falsified. His ontology could be seen as moderate conceptual or cautious realism. I have already mentioned Ganzevoort's social constructionist epistemology. As a consequence, reality to him is an idea that exists as a collective meaning construction.

The above shows that Van der Ven, Immink and Ganzevoort take different positions in the ontology and epistemology debate, and adhere to different research paradigms. A research paradigm embodies a particular view of the world, and a stance in relation to the nature of reality. As a result, our ontological assumptions, together with their epistemological implications, define our ideas of what research should be and which methods we should use to conduct it. Research paradigms, as a broad framework, comprehend which research strategies are possible. In answering a particular research question, researchers develop a design, comprising a research strategy, for their research. Producing new knowledge involves not only devising methods for generating and analysing data, but also a logic of inquiry, entailing the procedure for finding an answer and for arriving at the truth. Norman Blaikie distinguishes four research strategies: inductive, deductive, retroductive, and abductive (Blaikie 2007:8-11, 56-108). Each strategy solves quandaries in different ways. Each is a different style of reasoning that stems from the ontological standpoint of the researcher. Different researchers have different ontological preferences. They adopt a set of ontological assumptions that is sometimes not reconcilable with another set of compatible ontological and epistemological postulates, which can lead to the incommensurability of alternative research paradigms. Such irreconcilability of sets of assumptions means that there are more ways of conducting the research required, according to Blaikie (2007:204-205).

\section{CRITICAL REALISM}

In my latest research, I opted for a retroductive research strategy. Last summer, my book Faith in community, which describes a search for the meaning of the noun 'community' in the compound 'faith community', was published (Brouwer 2009). The question of the meaning of a congregation stating that it is a community was the starting point for ethnographic research into one particular congregation in the Protestant Church in the Netherlands. I decided to participate as a member in the specified congregation for about two years. In addition to attending the church nearly every Sunday, I also participated in small groups, an Alpha course, and numerous other activities. I even observed the church board meetings for a season, and attended their daily management meetings. Furthermore, I interviewed many different congregational members, read all of their key documents, and recorded their history in writing. For those two years, I was an example of what it meant to be a church member, at least when it came to participating. From within, I tried to grasp the meaning of 'community' for the congregation. My final analysis was a combination of the other members' self-perception and my interpretation. They told me how they perceived the congregation and its communal character. I then discussed their perceptions with them in terms of how I interpreted my personal experiences in the congregation, as well as in terms of the experiences of people outside the congregation.

My interpretation was informed by theories on community, on social capital, and on the biblical theological concept of koinonia. Out of these theories, I constructed a heuristic framework to observe and interpret the reality of the phenomenon 'community'. The theories and concepts helped me to perceive, distinguish, and recognise the phenomenon of community. Consequently, I delved into the empirical and theoretical literature on social capital and community and tried to find my way into the different approaches and persuasions that present themselves as a mer à boire (meaning, something that is difficult to achieve). Robert Putnam (2000; Putnam \& Feldstein 2003) opened my eyes to the significance of social capital and the bearing of religion. However, I define social capital, together with the sociologist James Coleman (1988), as the trust and reciprocity that exist in particular relations and situations that enable people to realise their expectations. Community I perceive, together with the sociologist Zygmunt Bauman, as a group of people who, for a considerable amount of time, share their experiences and goods, and take care of one another, being part of the same, localised life-world. Bauman criticises social constructionist approaches to community, in terms of which community is dislocated and disconnected from its geographical context. He refers to such communities as 'aesthetic' and as being distinct from the 'ethic', 'fraternal sharing' community, 'woven from long-term commitments, from inalienable rights and unshakeable obligations' (Bauman 2001:72).

However, it is fair to say that my opting for the theories of Coleman and Bauman was initiated by my interpretation of the biblical theological concept of 'koinonia'. After exploring the semantics of koinonia (Baumert 2003), followed by my excavating the practical theological (Kuhnke 1992) and ecclesiological (WCC 2005) processing of the concept, a type of stratified interpretation suggested itself to me. Semantically, 
the term 'koinonia' refers to sharing the same direction, and accompanying someone, though, over time, the term has become theologically encapsulated. Koinonia was perceived as a gift of God, with partaking in the gift meaning, ideally, the full communion of churches, on the one hand, and realising reciprocal justice and solidarity with the marginalised on the other. And, in an even more exactly theological sense, the phenomenon of koinonia was seen as corresponding to the relational character of the trinity, encompassing community and diversity. What was important to me in koinonia, next to its stratified content, was the heuristic question: What divine reality could be theologically identified with the concept of koinonia, and what might be the performative energy of this relational reality? Perhaps such a question is simplistic, but when Paul used the term 'koinonia' in the context of its semantic field for the first time in the history of Christianity, he was thinking in terms of which words could best describe what the God of Israel and the father of Jesus Christ was performing in the life of the first-generation Christians and their congregations. He was looking for words to fit their experiences, which were not privately owned, but shared, with such sharing being part of the experience. God's energy revealed itself in community. To describe such energised relationships, together with the community, the reciprocal obligations, and the mutual responsibility beyond the boundaries of class, sex, age, and race, Paul conceived of the term 'koinonia', coming to him as a revelation, I would say. Afterwards, the ecclesiological tradition took the ball and ran with it. By using the word 'koinonia', Paul constructed reality, though his reality was inspired by the reality of his experience. Beneath the multiple layers of interpretation in church history and systematic ecclesiology is still that reality that inspires experience. That is my presupposition, based on my own faith and that of others. Koinonia is interpreted experience that discloses God's performance.

The affinity with Immink's thinking here is the reason why I devoted the final chapter of my book to finding a common ground for the relationship between ontology and epistemology. At the end of this journey, which had some philosophy of science inclinations, I found a few interesting thoughts on reality in the work of the British theologian, Alister McGrath (2004, 2006). There might be some familiarity between McGrath's approach and the concept of 'transversality', as used by the South African American Wentzel van Huyssteen (1999), who borrowed this concept from Calvin Schrag: the transversal performance of reason, or the transversal play of rationality (Schrag 1992:148). However, Van Huyssteen's allergy to foundationalism and to fideistic traditions of rationality prompts him to prioritise the epistemological angle.

McGrath is in the process of designing what he calls a 'scientific theology'. Considering the research practices of the natural sciences, it is quite reasonable to presume that 'reality' exists and can be known through human observation. However, the nature of reality restricts our observations, and, with that, determines our knowledge of reality. McGrath states that ontology dictates epistemology. As a Christian theologian, McGrath perceives the creation narrative as an ontological foundation for understanding reality. In accordance with Alasdair McIntyre's 'tradition-mediated rationality', McGrath considers creation as an interpretative framework for reality and nature. He approaches reality as a combination of objectivity and social construction. He objects to radical social constructionism, although, in itself, social constructionism does not necessarily imply the denial of an objective reality. Although social facts are different from the hard facts of natural science, they are no less real and objective. For instance, social structures as the relations between social actors in social positions are real, because they enable or constrain actions. McGrath opts for a research paradigm called 'critical realism', inspired by the philosopher Roy Bhaskar. Critical realism moves between the Scylla of naïve realism and the Charybdis of postmodern anti-realism.

There are two things that McGrath borrows from Bhaskar. Firstly, reality exists independently from us, though we are involved in the knowledge constructing process. Scientific facts are interpreted facts. Furthermore, there is no universal epistemology, and there is no standard methodology that applies to all of science, as was assumed in modernist foundationalist paradigms. Bhaskar rejects what he calls the 'epistemic fallacy', namely the suggestion that reality is limited to what we can observe and know. Such a fallacy would entail a reduction of ontology to epistemology or methodology. In fact, it is the reverse: the nature of an object decides how we deal with it, and how we generate knowledge. Science needs to respond to the distinctive nature of its object. The second aspect McGrath adopts from Bhaskar is the stratification of reality. Every science deals with its own distinct layer of reality, with the methodology having to fit the specific layer. According to McGrath (2006:231), 'Each stratum demands its own methodology'. The methodology follows the ontology. Elaborating on Bhaskar's critical realism and his stratified reality concept, McGrath distinguishes several interconnected layers of reality that, as historical sediments, refer to revelation and God's action: texts; patterns of worship; confessional creeds; communities; institutional structures; and religious experiences. There is a 'multi-levelled imprint of revelation upon reality', and these 'original revelational events are embedded in a stratified way in historical reality' (McGrath 2004:211). Based on his critical realist paradigm, McGrath advocates a 'connectivist approach' of theology, in which the correlations between the layers in reality are researched. Furthermore, he promotes a 'cataphysic' approach of theology, which is an approach according to the nature of its reality. As the object or subject of theology is distinct, it requires a specific epistemic course and research strategy. McGrath says, for instance, that institutional structures can 'be investigated, within limits, by sociological methods, without being restricted by the assumption that only a social explanation of its origins may be offered' (McGrath 2004:213), which is an interesting thought in terms of the subject of my research, community.

Referring to the debate between Van der Ven, Immink, and Ganzevoort, McGrath's and Bhaskar's theories help me to understand the differences and similarities between the respective paradigms. Let me sum up my understanding of the debate in three concluding remarks. My first remark relates to McGrath's explanation that realism and social constructionism are not exclusionary options. Social constructions presuppose the existence of reality. So, on the one hand, Immink's rigid critique of social constructionism goes too far. However, on the other hand, more than just narratives, discourses, and performances exist. For instance, koinonia exists as both a social and a theological 'fact'. Of course, it is a social construct, but then again, as a collectivity in a historical context it is a construct that exists in reality. My second remark is that advocating a standardised and universal scientific methodology, as Van der Ven does, as a critical rationalist with a Popperian worldview, is no longer an option. A stratified model of reality, perceiving the nature of reality as emergent, layered and complex, points in the direction of multidisciplinary discourses. Furthermore, it helps to avoid forms of reductionism. Reality is a network, consisting of a web of life, and systems nested within other systems (Osmer 2008:181). One level of reality cannot be reduced to another. For instance, the 'realism of the text' (Van Huyssteen 1997:124-161), like the biblical concept of koinonia and its performative agency, cannot be reduced to the presence of social capital in a local congregation, or to the aestheticism of its communal character. My third concluding remark is that the 'Dutch' debate is, in fact, about the nature of reality and the cataphysic implications of empirical theology. Imminks seems to be afraid of losing the metaphysical moment, because Van der Ven emphasises the embeddedness of revelation in the empirical reality, at the cost of the theological dimension. However, prioritising the ontology of a stratified reality that reflects revelation should create a common ground.

Reality is complex and layered, and consists of multiple interconnected segments. Theological reality has more branches than just Scripture or sacramentality. There are phenomena, 
experiences, rituals, texts, artefacts, groups, structures, actors, and so on. Researching the interconnected layers of reality, with cross-disciplinary strategies, is a challenging scientific and theological task. Somehow, it amounts to detecting God in practice.

\section{REFERENCES}

Bauman, Z., 2001, Community. Seeking safety in an insecure world, Polity Press, Cambridge.

Baumert, N., 2003, Koinonein und Metechein - synonym? Eine umfassende semantische Untersuchung [Koinonein and Metechein - synonyms? A comprehensive semantical research], Verlag Katholisches Bibelwerk, Stuttgart.

Blaikie, N., 2007, Approaches to social enquiry: Advancing knowledge, Polity Press, Cambridge.

Brouwer, R., 1995, Pastor tussen macht en onmacht: Een studie naar de professionalisering van het hervormde predikantschap [Pastor between power and powerlessness], Boekencentrum, Zoetermeer.

Brouwer, R., 2009, Geloven in gemeenschap: Het verhaal van een protestantse geloofsgemeenschap [Faith in community], Kok, Kampen.

Coleman, J.S., 1988, 'Social capital in the creation of human capital', The American Journal of Sociology 94, suppl. Organizations and Institutions: Sociological and Economic Approaches to the Analysis of Social Structure, 95-120.

Ganzevoort, R.R., 2006a, 'The social construction of revelation', International Journal of Practical Theology, 10, 1-14.

Ganzevoort, R.R., 2006b, De hand van God en andere verhalen: Over veelkleurige vroomheid en botsende beelden [Hand of God and other stories], Meinema, Zoetermeer.

Ganzevoort, R.R., 2009, Forks in the road when tracing the sacred. practical theology as hermeneutics of lived religion, presidential address to the 9 th conference of the International Academy of Practical Theology, Chicago, 2009, viewed 21 December 2009, from http://www.ruardganzevoort.nl

Immink, F.G., 2002, 'Human discourse and the act of preaching', in C.A.M. Hermans et al. (eds.), Social Constructionism and Theology, Empirical Studies in Theology, vol. 7, pp. 147-170, Brill, Leiden.
Immink, F.G., 2004, 'Geloven: leven in de Godsgemeenschap: In gesprek met Johannes van der Ven [Faith: Living in communion with God]', Nederlands Theologisch Tijdschrift 58, 116-123.

Immink, F.G., 2005, Faith: A practical theological reconstruction, Wm B. Eerdmans Publishing, Grand Rapids, MI.

Kuhnke, U., 1992, Koinonia: Zur theologischen Rekonstruktion der Identität christlicher Gemeinde, [Koinonia. A theological Reconstruction of the Identity of the Local Church], Patmos Verlag, Düsseldorf.

McGrath, A.E., 2004, The science of God: An introduction to scientific theology, T\&T Clark/Continuum, London.

McGrath, A.E., 2006, A scientific theology: Reality, vol. 2, T\&T Clark/Continuum, London.

Oosterhuis, H., 2004, Verzameld liedboek: Liturgische gezangen, [Collected Hymns], Kok, Kampen.

Osmer, R.R., 2008, Practical theology: An introduction, Wm. B. Eerdmans Publishing, Grand Rapids, MI.

Putnam, R.D., 2000, Bowling alone: The collapse and revival of American community, Simon \& Schuster, New York.

Putnam, R.D. \& Feldstein, L.M., 2003, Better together: Restoring the American community, Simon \& Schuster, New York.

Schrag, C.O., 1992, The resources of rationality: A response to the postmodern challenge, Indiana University Press, Bloomington, IN.

Van der Ven, J.A., 1990, Entwurfeiner empirischen Theologie [Design of an empirical theology], Kok, Kampen.

Van der Ven, J.A., 1993, Practical theology: An empirical approach, Kok Pharos Publishing House, Kampen.

Van der Ven, J.A., 2002, 'Social constructionism and theology: A dance to be postponed?', in C.A.M. Hermans et al. (eds.), Social Constructionism and Theology, Empirical Studies in Theology, vol. 7, pp. 291-307, Brill, Leiden.

Van Huyssteen, J.W., 1997, Essays in postfoundationalist theology, Wm. B. Eerdmans Publishing, Grand Rapids, MI.

Van Huyssteen, J.W., 1999, The shaping of rationality: Toward interdisciplinarity in theology and science, Wm. B. Eerdmans Publishing, Grand Rapids, MI.

World Council of Churches [WCC], 2005, The nature and the mission of the Church: A stage on the way to a common statement [Faith and Order, paper 198], WCC, Genève. 